\title{
Propovjedništvo u Srbiji u 19. stoljeću
}

\author{
Mirko Mlakar*
}

\begin{abstract}
Sažetak
U članku se pravoslavno propovjedništvo u Srbiji tijekom 19. stoljeća prikazuje poglavito u socijalno-kulturnom kontekstu, a osobito se problematiziraju učinici rada dugogodišnjeg mitropolita Mihaila Jovanovića. Analiza aktera te jedine bogoslovije i drugih instrumenata (razvoja) propovjedništva upućuje na zaključak kako ni na kraju 19. stoljeća Beogradska mitropolija u toj djelatnosti ne dostiže razinu Karlovačke mitropolije (u Austro-Ugarskoj). Dok se na smjeni 19. u 20. stoljeće u Kraljevini Srbiji vide rezultati razvoja (visoke) svjetovne kulture u najširem smislu, uključujući govorništvo, u propovijedanju, koje je po ruskim uzorima, nema značajnijih pomaka. Uzroci zanemarivanja propovjedništva bili su unutar same izrazito nacionalno usmjerene državne religijske zajednice.

Ključne riječi: propovjedništvo, Kneževina/Kraljevina Srbija, Beogradska mitropolija, Karlovačka mitropolija, Mihailo Jovanović, pravoslavne bogoslovije
\end{abstract}

\section{Uvod}

Teško se ne složiti s tvrdnjom da je propovijed »jedan od jezgrenih sakralnih žanrova«, odnosno s O. A. Prohvatilovom koja u primarne žanrove »sakralnog funkcionalnostilskog kompleksa « uvrštava samo propovijed i molitvu. ${ }^{1}$ Propovjedništvo je zasigurno najbolji presjek, kumulativni i koncentrirani izraz aktivnosti predvodnika kršćanskih religijskih zajednica. Uostalom, »vjernici u velikoj mjeri vrjednuju cijelo bogoslužje upravo po homiliji. Svećenik je tu najviše izložen. $\aleph^{2}$ Uvid suvremenog katoličkog teologa iz Hrvatske vrijedi i za, primjerice, Srbiju u 19. stoljeću.

Ovaj se rad crkvenim govorništvom u Srbiji u 19. stoljeću bavi povijesno-razvojno, s naglaskom na socijalno-kulturnom kontekstu. Što se tiče istraženosti predmeta rada, prema bazi COBIB.SR, u knjižnicama u Srbiji nema knjige (mo-

* Dr. sc. Mirko Mlakar. Adresa: Hasana Kikića 7, 10140 Zagreb, Hrvatska. E-pošta: mvmlakar@ gmail.com

1 Usp. K. Končarević, Propoved kao žanr sakralne komunikacije: Lingvistički i lingvodidaktički aspekti, u: Srpska teologija u dvadesetom veku: Istraživački problemi i rezultati 15, B. Šijaković (prir.), Beograd, 2014, 153; 174.

2 Z. Pažin, Liturgijsko-teološko utemeljenje homilije, Diacovensia, 18, 3 (2010), 518. 
nografije) ili zbornika radova o srbijanskom ili uopće srpskom propovjedništvu u tom razdoblju. ${ }^{3}$ Prvo se poglavlje članka uglavnom bavi akterima, plodnijim govornicima u glavnim srpskopravoslavnim pokrajinama - u Karlovačkoj i Beogradskoj mitropoliji, a drugo problematizira školovanje i druge instrumente propovjedništva.

\section{Propovjednici}

Pišući o parosima (župnicima) »nesjedinjene religije « u »ilirskom narodu«, Friedrich Wilhelm von Taube, carski predstavnik na zasjedanju episkopata Karlovačke mitropolije, tvrdio je kako »većinom su to ljudi neznalice, čija se sva učenost sastoji u čitanju, pisanju i pjevanju«, te da »među njih 100 jedva se nađe jedan koji je sposoban držati propovijed «. ${ }^{4}$ Tada, u drugoj polovici 18. stoljeća, među boljim je propovjednicima (u Dalmaciji) i Dositej Obradović, monah koji je pobjegao iz manastira. Na početku 19. stoljeća zapuštenost klera u Beogradskom pašaluku (Smederevski sandžak) i u drugim zapadnim krajevima europskog dijela Osmanskog Carstva bila je gora od one kakvu je Taube bio zapazio u Slavoniji. Zato ne iznenađuje što je Petar Jovanović, Arhiepiskop Beogradski i Mitropolit Srbski od 1833. do 1859. godine, u Beogradu izazvao »vanredno neobično iznenađenje « kad je »svoju prvu besedu na izust izgovorio «. ${ }^{5}$

\subsection{Prečani i Srbijanci}

»Od većeg broja besednika iz krila sveštenstva s kraja XVIII i iz prve polovine XIX veka« vrijedi spomenuti protojereje (dekane) Stefana Uroševića, Jeftimija Ivanovića i Jovana Pavlovića, mitropolita Stefana Stankovića i vladiku Platona Atanackovića. ${ }^{6}$ Carigradska je patrijaršija 1831. autonomnoj Srbiji (knjaz Miloš Obrenović) priznala samoupravu, te je mitropolit Petar morao uvoditi red u bogoslužje i organizirati osnovne crkvene poslove, uključujući kontinuitet bogoslovije. Osnovana je 1836., a takva škola u Sr(ij)emskim Karlovcima radi od 1794. godine. Propovjedništvo u Srbiji tek se počelo razvijati i razumljivo je zašto su od navedene petorice - među kojima je napose episkop Platon bio značajniji kao društveno-politički nego kao vjerski govornik — četvorica iz Karlovačke mitropolije, a ni šabački protojerej Jovan nije bio rođen u Srbiji, nego u Bosni.

Inače, »za besedništvo ovog perioda moglo bi se reći da se jasnom linijom vezuje za srednji vek i srednjovekovnu retoriku, a drugom, isto tako vidljivom, ono se kretalo u okvirima baroknog i klasicističko-racionalističkog manira nego-

3 U bazi Virtuelna biblioteka Srbije pretraživali smo ključne riječi propovedništvo, omilitika i sl. URL: http://www.vbs.rs/scripts/cobiss?ukaz=getid\&lani=sr (preuzeto 05.05.2016.)

4 F. W. von Taube, Povijesni $i$ zemljopisni opis Kraljevine Slavonije $i$ vojvodstva Srijema, Osijek, 2012, 64; 71-72.

5 Usp. R. M. Grujić, Pravoslavna Srpska Crkva, Beograd - Kragujevac, ${ }^{3} 1995,153$.

6 Usp. M. Đorđević, Besedništvo kod Srba, Niš, 2007, 224. 
vanog u Poljskoj, Rusiji i Ukrajini «.7 Teološko-filozofsko-književna preplitanja vide se još u prvoj polovici 18. stoljeća (Gavril Stefanović Venclović i drugi), a u prvoj je polovici 19. stoljeća racionalistički diskurs, koji dolazi i ruskopravoslavnim posredovanjem, istisnuo bizantsko-srpske matrice.

Prema citiranom istraživaču, »duhovno besedništvo XIX veka obeležila su « šestorica vladika: užički Janićije/Joanikije Nešković, šabački Gavrilo Popović i Samuilo Pantelić, pakrački Nikanor Grujić, bokokotorski Gerasim Petranović i gornjokarlovački Teofan Živković, a »značajni duhovni besednici« bili su i mitropolit Melentije, arhimandrit Firmilijan i Sergije Kaćanski. ${ }^{8}$

Znakovito je da je »dobar i čuven narodni propovednik « Gavrilo Popović rođen u Bačkoj, ${ }^{9}$ a u Srbiju je prešao na poziv mitropolita Petra Jovanovića. Jovanović (rođen u Iloku) i Popović (iz Baje) bili su prečanski Srbi — od preko, s onu stranu Save, Dunava i Drine, odnosno nisu Srbijanci, a ni Crnogorci ili Srbi iz (drugih) dijelova Osmanskog Carstva južnije od tadašnje Srbije. Prečani su bili nužni osmanskoj vazalnoj kneževini koja je oskudijevala u obrazovanim ljudima. ${ }^{10} \mathrm{Na}$ poziv još jednog prečanskog Srbina — mitropolita Teodosija Mraovića (rođen u Baji, poglavar 1883.-1889.), u Srbiju je prešao i Samuilo Pantelić. Taj se Srijemac odlikovao »besedničkim darom i odličnim poznavanjem crkvenog pojanja ${ }^{11}$

Prečanin koji nije dolazio u Srbiju bio je vladika Sergije. »Besede Sergija Kaćanskog, pod naslovom Toržestvo dobrodetelji, gde se izlaže hrišćanska etika manje-više onako kako je bila shvatana u rimokatoličkim i protestantskim etikama «, ${ }^{12}$ tiskane su 1863. u Novom Sadu. Melentije Pavlović bio je, poslije niza fanariotskih (grčkih), prvi srpski mitropolit u Beogradu (1831.-1833.), a Firmilijan Dražić, koji je 1903. umro kao skopski mitropolit, 1885. objavio je »prvu kapitalnu knjigu « Tumačenje jevanđelja sa besedama. ${ }^{13}$

Da je »duhovna književnost« u Srbiji 1868. »uglavnom propovedničkog karaktera (moralnog sadržaja)«, pokazuju radovi episkopa Joanikija Neškovića i sv. Bazilija Velikog u prijevodu episkopa Gavrila Popovića. ${ }^{14}$ Zapravo, srpska teologija 19. stoljeća »nije sadržana toliko u studijama i stručnim raspravama koliko u liturgijskim propovedima«, tako da Nikanor Grujić, Teofan Živković,

7 Isto.

8 Usp. Isto, 224-225. Gornjokarlovački episkop stoluje u Karlovcu (ili Plaškom).

9 Usp. R. Grujić, Pravoslavna Srpska Crkva, 153-154.

10 Od 70 učitelja, koliko ih je 1836. bilo u Srbiji, 50 je iz»Ćesarevine«, a u početku su svi profesori Liceja i članovi Društva srpske slovesnosti bili Srbi »iz preka« (usp. S. M. Ćirković, Srbi među europskim narodima, Zagreb, 2008, 222).

11 Usp. S. Vuković, Srpski jerarsi: Od devetog do dvadesetog veka, Beograd et al., 1996, 437.

12 R. Bigović, Od Svečoveka do Bogočoveka: Hrišćanska filosofija vladike Nikolaja Velimirovića, Beograd, 1998, 20.

13 Usp. R. Grujić, Azbučnik Srpske pravoslavne crkve: Po Radoslavu Grujiću, S. Mileusnić (prir.), Beograd, 1993, 74-75.

14 Usp. I. Marković, Počeci književnog rada učenika i profesora beogradske Bogoslovije. URL: http:// pravoslavlje.spc.rs/broj/1061/tekst/poceci-knjizevnog-rada-ucenika-i-profesora-beogradskebogoslovije/ (preuzeto 04.11.2013.) 
Nikanor Ružičić, Mitrofan Ban i drugi vladike te Jovan Vučković, Jovan Jeremić, Vladimir Milutinović, Vasa Nikolajević, Jovan Buta i drugi prezbiteri »štampali su svoje besede onim intenzitetom i poletom kakvim se danas publikuju akademsko-bogoslovski ogledi i kritike «. ${ }^{15}$

Navedeni su svećenici stvarali u Karlovačkoj mitropoliji. Pogleda li se, pak, gdje su rođeni i djelovali vladike koje se izrijekom spominju — Grujić, »jedan od najboljih besednika svoga vremena«; Živković, »najbolji besednik devetnaestog veka u Karlovačkoj mitropoliji«; crnogorski mitropolit Mitrofan, koji se, iako bez redovnog obrazovanja, »istakao i kao bogoslovski pisac« te su tiskane njegove izabrane besjede — vidi se kako je iz tadašnje Srbije samo žički i niški episkop Nikanor Ružičić. ${ }^{16}$ Ali, Srbijanac je bio i Mihailo Jovanović (1826.-1898.).

\subsection{Mitropolit Mihailo}

Budući da je već 1854. izabran za vladiku, Mihailo Jovanović nije stigao »zagrijati stolicu « nastavnika dogmatike i homiletike. Beogradski je mitropolit od 1859. godine, nakon iznuđene ostavke Petra Jovanovića, a poslije je i sam uklonjen. Vlast kneza Milana Obrenovića 1881. zbacila je toga rusofilsko-panslavenski usmjerenog nacionalnog radnika koji nije bio po volji Beča, instalirala je naprednjačku hijerarhiju na čelu s Teodosijem Mraovićem, ali je Jovanović opet postao mitropolit 1889., nakon abdikacije Milana, kralja od 1882. godine.

Prema prosudbi s početka 20. stoljeća, mitropolit Mihailo je u Srbiji »prvi pravi i do danas najodličniji bogoslovski pisac « s pedesetak radova i »jedan od najboljih propovednika «. ${ }^{17} \mathrm{U}$ njegovim je propovijedima $» l i c ̌ n i$, personalistički bogoslovski pristup sveden na najmanju moguću meru i umesto njega primetna je široka podložnost kolektivističkim životnim obrascima ${ }_{.}^{18}$ Među ostalim, kolektivizam je opća pojava europske nacionalnointegracijske epohe, koja u srpskom slučaju znači političke, duhovne i ostale radove na oslobođenju i ujedinjenju svih Srba (i Jugoslovena), čemu su se podlagali i drugi propovjednici.

Do Mihaila Jovanovića »nije gotovo ni bilo bogoslovske književnosti u obnovljenoj Srbiji«, jer »ostaci stare književnosti, s padom pismenosti, bili su gotovo sasvim zaboravljeni, a novija književnost iz Mitropolije Karlovačke iz istih se razloga nije mogla širiti.$^{19}$ Početkom 19. stoljeća u Srbiji je vladala gotovo opća nepismenost, a u patrijarhalno-agrarnoj zemlji stanje se do kraja stoljeća nije značajnije promijenilo. Na početku 20. stoljeća nepismenih je bilo $79 \%$,

15 Usp. I. Živković, Propovedništvo mitropolita Mihaila, Crkvene studije, 1, 1 (2004), 162. Naravno, govornici su objavljivali i stručne radove. Primjerice, krajem stoljeća — kad se raspravljalo o tome »zašto popina propoved nema značajnoga utiska na narod « - Vučković je napisao »Protivuhrišćansku struja sa Zapada i naše propovedništvo« (usp. B. A. Cisarž, Jedan vek periodične štampe Srpske pravoslavne crkve II: Bibliografski opis časopisa i listova sa pregledom-sadržajem svih radova objavljenih u njima od 1868-1970, Beograd, 1991, 198-205).

16 Usp. S. Vuković, Srpski jerarsi, 357; 492; 322.

17 Usp. Grujić, Crkva, 153.

18 Usp. I. Živković, Propovedništvo mitropolita Mihaila, 166.

19 Usp. Grujić, Crkva, 153. 
dok je više od polovice srpske populacije u Ugarskoj pismeno. ${ }^{20}$ Nepismenost je veliki indikator i faktor kulturne nerazvijenosti, koja ograničava razvoj crkvene misli i djelovanja, što se zasigurno, u interakciji s drugim činiteljima, očituje i kao razlika u broju važnih/ili plodnih propovjednika u Karlovačkoj i Beogradskoj mitropoliji. Srbijanski se pošiljatelji religijskih poruka nisu isticali visokom funkcionalnom pismenošću i predanošću. Primjerice, šabački vladika Dimitrije Pavlović zapaža da je među sto svećenika njegove eparhije (dijeceze) samo 25 članova Srpske književne zadruge, malo ih se bavi pisanjem i u kleru se vidi »nazadak u intelektualnom razvijanju, dok učitelji i u tom pogledu naglo napreduju «. ${ }^{21}$

Još je beogradski mitropolit Petar od svećenika tražio da »tačno i na vreme vrše bogosluženje, da u nedeljne i praznične dane narodu drže propovedi «, te da osobnim životom daju dobar primjer pastvi. ${ }^{22} \mathrm{U}$ prilog tvrdnji da je »trudom Mitropolita Mihaila otpočeo proces ponovnog saobražavanja srpskog pravoslavlja svetom predanju Crkve« — a »pre svega to je značilo obnovu angažovanja sveštenih pastira na pripremi propovedanja « — navodi se i to da u »Arhijerejskoj poruci novorukopoloženom svešteniku « propovijedanje stavlja među glavne obveze: »Dužan si, što češće možeš, tumačiti svojim parohijanima Simvol vere, Deset Božjih zapovesti i Molitvu Gospodnju, pa za to ćeš u nedeljne i praznične [dane] čitati na Svetoj Liturgiji poučne besede ili iz katihizisa glavnije istine naše vere i ove objašnjavati «. ${ }^{23}$ Među ostalim, episkopatu je 1890. predložio da svećenici nedjeljama i blagdanima drže jednostavne »besede u Crkvi i na skupovima « te da se oni koji se trude »odlikuju i nagrađuju «. ${ }^{24}$

Ocjena je da su političke i crkvene besjede Nikanora Grujića »sklopljene po svim pravilima govorničke umetnosti«, ali nisu usiljenje, te je on »bez sumnje najveći srpski besednik u devetnaestom veku«.25 Ako i nije bio najveći srpski propovjednik, mitropolit Mihailo sigurno je bio glavni besjednik u Srbiji u 19. stoljeću te je najviše uradio za razvoj srpskog propovjedništva. No, iako je »dosta učinio za dobro poverene mu crkve«, »crkvenom progresu « smetala je Jovanovićeva »slabost i mekost, i disciplina je u sveštenstvu jako pala«, a i bio je »izraziti političar i aktivan predstavnik jedne stranke «. ${ }^{26}$ Čak ako njegovo mje-

20 Usp. S. Ćirković, Srbi među europskim narodima, 258. Tad udio nepismenih u Finskoj (autonomna u Ruskom Carstvu) iznosi $7 \%$, u Italiji $48 \%$, u Hrvatskoj i Slavoniji $55 \%$ te u Dalmaciji $73 \%$. Bugarska i Rumunjska imaju postotak nepismenih otprilike kao u Srbiji. Usp. S. Leček, Pokušaji smanjivanja nepismenosti u Banskoj Hrvatskoj početkom 20. stoljeća, Radovi Zavoda za hrvatsku povijest, 26 (1993), 140.

21 Usp. A. D. Sredojević, Patrijarh srpski Dimitrije Pavlović (1920-1930) : Doktorska disertacija, Beograd : Filozofski fakultet Univerziteta u Beogradu, 2013, 163. URL: https://fedorabg.bg.ac.rs/ fedora/get/o:9478/bdef:Content/get (preuzeto 05.05.2016.)

22 Usp. Đ. Slijepčević, Istorija Srpske pravoslavne crkve, Beograd, 2002, 335.

23 Usp. Živković, Propovedništvo, 167.

24 Usp. Isto.

25 Usp. A. Gavrilović, Znameniti Srbi XIX veka, Beograd, 1990 [izvornik: Zagreb, 1901-1904], II-16.

26 Usp. R. Grujić, Azbučnik Srpske pravoslavne crkve, 103. Jovanović, čovjek »blage naravi« i pobožan, nije uvijek uspijevao »srećno upravljati« klerom kakav je bio pod njegovom vlašću te »nije mogao drugima uliti« pobožnost. Usp. M. Đ. Milićević, Dodatak Pomeniku od 1888: Znameni- 
sto u vrhu Liberalne stranke nije izravno negativno utjecalo na propovijedanje, kler je upućivalo na to da je (zabranjivano) bavljenje politikom zapravo poželjno koliko i bavljenje propovijedima i drugim izvornim crkvenim zadaćama. Štoviše, »mnogi sveštenici i monasi su bili više u službi nacionalnoj ideji nego veri«, odnosno »sveštenici su se isticali na političkim zborovima i bili su agilniji u vođenju političkih poslova nego u obavljanju verskih dužnosti«.27

Samo četverosveščani Pravoslavni propovednik mitropolita Mihaila ima više od 1.900 stranica. ${ }^{28}$ Ali, reklo bi se da desetljeća označena Jovanovićem nisu doba zamaha propovjedništva, koji ni ne može biti pothvat pojedinca, makar bio najodgovornija osoba religijske zajednice. Propovijedanje se ne intenzivira ni u doba Inoketnija Pavlovića, mitropolita od 1898. do 1905. godine. Za razliku od Jovanovića, on je pisao samo »kitnjasto-isprazne duhovne besede ${ }^{29}$ te, kako stoji u oficioznom biografskom leksikonu, »kao poglavar Srpske crkve u Srbiji nije ostavio nekog naročitog traga «.30

ti ljudi u Srpskoga Naroda koji su preminuli do kraja 1900 g., Beograd, 1901, 95. URL: https:// archive.org/stream/pomenikznamenit00miligoog\#page/n1001/mode/2up (preuzeto 05.05.2016.) Postoje i argumenti za ocjenu da je mitropolit Mihailo bio »prilično strog « (Živković, Propovedništvo, 168).

27 Usp. R. Radić, Narodna verovanja, religija i spiritizam u srpskom društvu 19. i u prvoj polovini 20. veka, Beograd, 2009, 86.

28 Besjeda »O presvetoj Troici« spada u mitropolitove govore bez kerigmatske snage, u katehetskoj dimenziji svedena je na nizanje citata i slab je poticaj življenju vjere (usp. /Jovanović/ Mihailo, Pravoslavni propovednik II, Beograd, 1866, 189-194), te ni poslije Jovanović ne postiže umijeće, primjerice, hersonskog vladike Dimitrija Muretova da približi i najsloženije dogmatske teme. Mladi je mitropolit više nadahnuća i umijeća pokazao govoreći o »kalamljenju boginja «, biblijski i medicinski argumentiranoj raspravi s onima koji tvrde da je od Boga život i smrt, uključujući smrt djeteta kao posljedicu uvjerenja da je cijepljenje protiv boginja »pečat antihristov « (usp. Isto, 582-590). U obraćanju onima koji su nepismeni ili ne čitaju »sveštene knjige«, mitropolit ističe da »i sam Gospod Bog, neće da spase vas, ako vi ostanete nemarni, ako sami ne vodite brigu za spasenje svoje duše« (usp. Isto, 59-66). U doba u kojem vlada otpor i prema korištenju poljoprivrednih alata, Jovanović piše da se muškarci za blagdana napijaju i zlostavljaju obitelj, a da su pismeni, uzeli bi duhovnu ili svjetovnu knjigu, te onima kojima je kasno za opismenjavanje savjetuje da djecu daju u školu, te tako pomognu svećenicima koji žele da ona nauče čitati i razumijevati svete knjige »za sreću svoju i za slavu Boga i Gospoda Isusa Hrista« (usp. isto). Može se reći, na temelju (zasad) parcijalnog uvida, da je u mitropolita uz naviještanja izrazitija i funkcija naučavanja, više nego u homilijama i drugim govorima, primjerice, Nikanora Grujića (Crkvene besede, Zemun, 1892), pa i Gerasima Petranovića (Dobri pastir I, Zagreb, 1851), te da ta trojica suvremenika postižu slične propovjedničke domete. Prema istraživaču govorništva (koji je bio u prilici slušati mitropolita), Jovanovićeve su besjede »sadržajno i izražajno bile retorske«, ali on ipak ne spada u velike duhovne govornike, nego se propovijedanje uzdiže do »prave umetničke visine « tek u 20. stoljeću, s pojavom Nikolaja Velimirovića (usp. B. Đ. Nušić, Retorika: Nauka o besedništvu, Beograd, 21938, 241).

29 Usp. R. Pilipović, Srpski bogoslovi na školovanju u Rusiji u drugoj polovini XIX veka — prema oceni ruskog carskog diplomate [I], Godišnjak za društvenu istoriju, 19, 1 (2012), 85.

30 Usp. Vuković, Jerarsi, 198. 


\section{Propovijedanje}

Prema mišljenju niškog vladike Dimitrija Pavlovića, narod je bio spreman ispuniti i »unutarnju stranu vere« te je željno slušao religioznu pouku — ako je bilo svećenika koji je bio u stanju propovijedati i riječima i djelima. ${ }^{31} \mathrm{U}$ jednom Pavlovićevom izvještaju episkopatu stoji kako »inteligencija «̌̌eli da se sva bogoslužja poprate poukama, a po selima su blagonakloni prema kleru koji drži propovijedi, te se, time potaknuti svećenici, ako su školski spremni, nadmeću u propovijedanju. ${ }^{32}$ Poslije, kao šabački vladika, Pavlović izvještava da »besedništvo, ako ga ima, biva samo po nuždi i na zapovest pretpostavljenih vlasti, a retko se ko od sveštenika zagrejao pravom apostolskom revnošću u propovedništvu. «33 Časopis Hrišćanski vesnik objavio je 1902. tekst u kojem Nikola (budući veliki govornik Nikolaj) Velimirović tvrdi da »beseda u nas nije sastavni deo službe; hoće li ona to biti il' ne biti zavisi od raspoloženja sveštenika«, koji nisu u stanju da izazovu »ni običnu zainteresovanost«, pa je za vrijeme inače rijetkih i prekratkih propovijedi »mnogobrojno izlaženje« vjernika iz crkve. ${ }^{34}$

\subsection{Homiletika}

Kratka je propovijed bila preporuka udžbenika koji je 1894. Svetolik Ranković napisao prema sustavu Nazarija Tavorova s Kijevske duhovne akademije. ${ }^{35} \mathrm{U}$ Omilitici (Upustvu za crkveno propovedništvo) jednostavnost, kratkoća i domoljublje navode se kao »naročite osobine « srpskog propovjedništva, a radi poučnosti propovijed mora biti u religioznom i nacionalnom duhu, ističe istraživač koji

31 Usp. A. Sredojević, Patrijarh srpski Dimitrije Pavlović, 125.

32 Usp. Isto, 86.

33 Isto, 164. Kad episkop Sava u programatskom govoru kaže »spremajmo dostojne karakterne propovednike srpske crkve, koji će ne samo tek lepim rečima kao forme radi govoriti, nego koji će i posvednevnim dobrim i istino-hrišćanskim vrlinama da prednjače — čime će srca svojih vernih zadobiti« (usp. S. Dečanac, Beseda kojom je predsednik Gl. Odbora svešteničkog udruženja, episkop žički Sava Dečanac otvorio I redovni godišnji skup Sv. Udruženja, Beograd, 1890, 12), otvaraju se pitanja o homiliji kao bitnom dijelu liturgije i važnosti liturgije u Crkvi. Među ostalim, valjda homilija i liturgija također djeluju na »srca«. Inače, vladika (čija je retorika označena kićenošću) ističe da »govoriti o srpskim propovednicima vere i morala, to je isto što govoriti i pisati o celokupnoj povesnici, razviću i sudbini celokupnog srpskog naroda, i obratno« $($ Isto, 5).

34 Usp. N. Velimirović, Naše crkveno besedništvo, u: N. Velimirović, Sabrana dela II, Himelstir, 1986, 27-29. Za podrobnu analizu propovijedi vidjeti i: B. A. Cisarž, Bibliografija propovedi štampanih u crkvenim časopisima za poslednjih sto godina: 1868-1970, Novi Sad, 1975.

35 U tri desetljeća na kraju 19. stoljeća Kijevsku akademiju pohađalo je više od 70 Srba, a završilo ju je, uglavnom zbog loše »predspreme«, samo 48, od čega je svaki drugi dolazio iz Srbije. Usp. V. Puzović, Završni radovi Srba na Kijevskoj duhovnoj akademiji (1869-1899), u: Srpska teologija u dvadesetom veku: Istraživački problemi i rezultati 12, B. Šijaković (prir.), Beograd, 2012, 153-157. Sudeći prema temama 36 završnih radova o kojima postoje podatci (usp. Isto, 165-170), barem bi dva spadala u homiletiku. Oba su 1888. kod Vasilija Pjevnickog obranili Srbijanci: propovijedi sv. Grgura Nisenskog obradio je Dimitrije Milenković, a Ranković »Stanje crkvene propovedi u Srbiji u tekućem stoleću«. U dostupnoj literaturi nisam našao citate iz toga Rankovićeva rada ili nešto u vezi s njim. 
citira Rankovića. ${ }^{36}$ Prema Omilitici, kako bi propovijed bila »verno ogledalo narodnog života, tj. njegovih mišljenja i navika, nacionalnih osobina i osećanja «, uvjet je da se propovjednik »srodi sa narodom «, te da u gotovo svakoj propovijedi »pored pravog hrišćanskog duha, provejava $i$ duh srpskog patriotizma ${ }^{37}$ U propovijedima drugih naroda nema toliko patriotizma, a »najbliža srpskoj je ruska duhovna propoved, u kojoj je pak živo provedeno poznato rusko načelo samoderžavija « (despotizma). ${ }^{38}$ Rankovićevo »više sekularizovano viđenje stvari prokrijumčareno u sam sistem omilitike biće postepeno neutralisano u narednim decenijama, što publikovanjem omilija Vladike Nikolaja [prva zbirka 1912.], što srpskim izdanjem V. Pjevnickog i njegove Crkvene rečitosti [1931.], ali i prevodom Dobrih saveta propovednicima Jevanđelja Čarlsa Spurdžona [1909.], najvećeg hrišćanskog propovednika epohe«, zaključuje Živković. ${ }^{39}$

Boljim se udžbenikom čini Omilitika ili Nauka o crkvenoj slovesnosti, koju je 1861. mitropolit Mihailo sastavio na temelju djela svojeg kijevskog profesora Jakova Amfiteatrova. Propovijed bi trebala izražavati »duh Biblije i Crkve prigođen duhu naroda «, a kad se kaže da crkveni govor »mora imati ova tri svojstva: religioznost, pravoslavije i narodnost «, teolog na početku 21. stoljeća upozorava na to kako se narodnost određuje u smislu da »propoved treba da je opštenarodna, tj. da je opšteudesna« i da se može »sazidavati svuda i na svakom mestu, pred celim svetom $«{ }^{40}$ Ali, prije i poslije mitropolita Mihaila (i Rankovića), propovijed istočnih »narodnih Crkava« ima »versko-nacionalni karakter«, pri čemu je između legitimnog zakona popularnosti (Pjevnicki) te zakona populizma, pa i onog nacionalnog, »veoma tanka linija razgraničenja «. ${ }^{41}$

Jovanović je napisao, priredio prema ruskim izvornicima i/ili dao objaviti $\mathrm{Pa}$ stirska poučenija (1860.), Crkvenog učitelja (1861.) i druge govornicima korisne radove. Njegov »trud na opskrbljivanju sveštenstva primerenim modelima beseda ostaće bez premca u kasnijim arhijerejskim poduhvatima u Srbiji - u 20. veku će mu se na tom polju donekle približiti Episkop Nikolaj Ohridski i Episkop Stefan Žički «. ${ }^{42}$

Laik Ranković, upamćen kao dobar književnik, homiletiku je na Bogosloviji kratko predavao, a od profesora klerika zasigurno je najplodniji bio Dobrosav Kovačević, autor Svetog Save kao propovednika Srpske pravoslavne crkve sa prilogom njegovih propovedi (1901.) i sličnih kraćih radova. Uopće, Srpska Pravoslavna Crkva »ne može se pohvaliti nekim značajnijim teorijskim radovima iz omilitike ${ }^{43}$

36 Usp. Živković, Propovedništvo, 170.

37 Usp. Isto.

38 Usp. Isto.

39 Isto.

40 Usp. Isto, 169-170.

41 Usp. Isto, 176.

42 Isto, 168-169. Propovijedi Stefana Boce počele su se objavljivati u knjigama još dok je bio dalmatinski vladika (Pazimo na vreme I, Šibenik, 1976).

43 Usp. B. A. Cisarž - Ž. M. Marinković, Omilitika ili teorija crkvenog govorništva, Beograd, 1969, 59. 


\subsection{Bogoslovija}

U vrijeme kad je Petar Jovanović postao mitropolit (1833.), većina protojereja i drugih svećenika te monaha »jedva je znala čitati i pisati«, a kad je morao podnijeti ostavku (1859.), samo petina svećenstva nije završila bogosloviju. ${ }^{44} \mathrm{U}$ školi osnovanoj 1836. godine, koja u drugoj polovici stoljeća prima kandidate $\mathrm{s}$ barem četiri razreda gimnazije, govorništvo formalno ima dobar status. Primjerice, školske godine 1882./1883. Dimitrije Pavlović predaje retoriku (2. razred — četiri sata tjedno), homiletiku (3. razred — dva sata) i govorništvo (4. razred — dva sata). ${ }^{45}$ Pogleda li se raspored na početku 1887. godine, u vrijeme rektora Nikodima Milaša, vidi se da je u ukupnom tjednom fondu od 76 sati za sedmoricu nastavnika (tj. profesora) homiletika zauzimala četiri sata u 4. razredu, dok se, primjerice, dogmatika poučavala sedam sati (četiri u 3. i tri u 4. razredu), moralna teologija $\mathrm{i} »$ obredoslovlje« po tri sata (u 3. razredu) itd. ${ }^{46}$

Jedinu srbijansku obrazovno-odgojnu ustanovu za svećenički po(d)mladak pohađali su u pravilu slabiji đaci, te se često upozoravalo da su iz te stručne škole, koja nije bila zahtjevna poput, primjerice, Vojne akademije, izlazili slabo obrazovani. S polaznicima se nije primjereno radilo, pa je Milaš, pozvan iz Zadra da reorganizira Bogosloviju (što nije uspio), ministru pisao kako je učenike zatekao bez ikakvog nadzora i da »nemarnost prema školi i crkvi bila je u najvišem stupnju ${ }^{4}{ }^{47}$

Uz beogradsku školu, koja je bila najveća, krajem stoljeća teološku spremu na srpskom jeziku nudilo je još pet škola u tri države: Austro-Ugarskoj (Srijemski Karlovci, Zadar i Reljevo pokraj Sarajeva), Kneževini Crnoj Gori (Cetinje) i Osmanskom Carstvu (Prizren). Za upis u tri austrougarske bogoslovije ( $\mathrm{BiH}$ je nakon okupacije samo nominalno pod sultanom) u pravilu se tražila završena osmogodišnja gimnazija (što se nije uvijek moglo postići). I na račun najstarije i najkvalitetnije škole, one u Srijemskim Karlovcima, moglo se čitati kako »bolje je zatvoriti bogosloviju, nego da nam zbog nje obraz crveni ${ }^{48}$ Ali, realnija je (pr) ocjena da je Bogoslovija u Beogradu »skoro gora od sviju prosvetnih ustanova ove vrste u Srpstvu «, te da je »površnost « teološkog i svjetovnog obrazovanja poglaviti »uzrok nedovoljnog našeg crkvenog besedništva «i posredno »glavni uzrok antireligijoznom stanju « u Srbiji. ${ }^{49}$ Prema rektoru Stevanu Veselinoviću, stanje teologije bilo je »nezavidno, ali i ne sasvim očajno «. 50

44 Usp. R. L. Veselinović, Istorija Srpske pravoslavne crkve sa narodnom istorijom II: 1766-1941, Beograd, 1966, 123.

45 Usp. Sredojević, Patrijarh, 23.

46 Usp. P. Puzović, Nikodim Milaš, rektor beogradske Bogoslovije, u: P. Puzović, Prilozi za istoriju Srpske pravoslavne crkve I, Niš, 1997, 226-227.

47 Usp. Izveštaj rektora bogoslovije arhimandrita dr-a Nikodima Milaša o stanju bogoslovije, Prosvetni glasnik, 8, 9 (1887), 341. Među ostalim, učenici su živjeli u neprimjerenim uvjetima, a »religioznosti čak ni u najvažnijim momentima liturđije nije se kod njih opažalo« (Isto, 341-344).

48 Usp. N. Gavrilović, Karlovačka bogoslovija: 1794 - 1920, Sremski Karlovci, 1984, 73.

49 Usp. N. Velimirović, Naše crkveno besedništvo, 30-31.

50 Usp. S. Veselinović, Više bogoslovsko obrazovanje, Vesnik Srpske crkve, 18, 2 (1907), 81-82. 


\subsection{Periodika}

Pravoslavna crkva u Kneževini/Kraljevini Srbiji bila je pod dominantnim ruskim utjecajem, a u periodici, sredstvu cjeloživotnog (in)formiranja klera, rijetko se posreduju iskustva iz bližeg pravoslavnog okruženja: rumunjska, bugarska i grčka. Najviše se prevode ruski no nisu zapostavljeni ni zapadnokršćanski autori: Hrišćanski vesnik1880. godine nudi misli Françoisa Fénelona o »crkvenom krasnorečju«, 1892. Vesnik Srpske crkve »Karakternu osobinu i metodu sastavljanja propovedi«, prijevod rada (američkog episkopalca) Phillipsa Brooksa itd. ${ }^{51}$

Povjesničarka primjećuje da »mada su u Srbiji prevođene crkvene besede i spisi znamenitih ruskih crkvenih pisaca i besednika, oni nisu bili bliski vernicima, a u zemlji nije bilo jakog teološkog mislioca sposobnog da ruske ideje prilagođava srpskim uslovima ${ }^{52}$ Među ostalim, mitropolit Mihailo sastavio je Omilitiku po Amfiteatrovu, koji se umjesto korištenja francuskih obrazaca »vraća patrističkoj propovedi «. ${ }^{33} \mathrm{~S}$ druge strane, mladi Nikola/Nikolaj Velimirović u za ono vrijeme obimnom radu ne samo da ne navodi ni jednog srpskog uzornog propovjednika, nego ne spominje (arhi)episkopa Inokentija Borisova (Ruski Zlatousti) ili nekog drugog ruskog praktičara i/ili teoretičara propovjedništva, nego od velikana, uz kanonskog sv. Ivana Zlatoustog, spominje Jacques-Bénignea Bossueta i Louisa Bourdalouea. ${ }^{54}$

O učincima djelovanja osobito mitropolita Mihaila može se zaključivati i po tekstu (u kojem se zastupa stav da je snaga propovijedi više u dojmljivosti nego u sadržaju) nastalom i zato što je svećenik koji je »držao improvizoranu posmrtnu reč« pozvan na odgovornost (u doba mitropolita Inokentija). ${ }^{55}$ Nakon prijevoda članka ruskog svećenika koji se zalaže za improvizaciju, a ne čitanje propovijedi, prevoditelj piše da se u Srbiji »skoro nikako« ne besjedi ili se to radi »naopačke«, pa su propovijedi loše sadržajem ili izvedbom, odnosno u Rusiji, gdje su rezultati govorništva »dosta neznatni«, i u Srbiji, gdje su »odveć ništavni«, od desetorice mladih svećenika koji su dobro izučili homiletiku postat će dva-tri dobra govornika, dok ce ih u protestanata i katolika biti mnogo više. ${ }^{56}$

51 Usp. B. Cisarž, Jedan vek periodične štampe Srpske pravoslavne crkve II, 199, 200.

52 R. Radić, Narodna verovanja, religija i spiritizam u srpskom društvu 19. i u prvoj polovini 20. veka, 90.

53 Usp. G. Florovski, Putevi ruskog bogoslovlja, Beograd et al., 2009, 212. Glavno je obilježje Predavanja (Čitanja; Чтенияоцерковнойсловесности, илиГомилетика, Киев, 1846.), koja su poslužila kao temelj za stvaranje »ruskog nacionalnog stila propovijedanja«, »odbacivanje nasljedovanja zapadnoeuropskih katoličkih i protestanskih obrazaca te usmjeravanje na bizantsku i starorusku propovijed «. Usp. А. А. Волков, АмфитеатровЯковКосмич, Православнаяэнциклопедия II, Москва, 2001. URL: http://www.pravenc.ru/text/114656.html (preuzeto 05.05.2016.)

54 Usp. Velimirović, Besedništvo, 27.

55 Usp. D - n., »Živa reč« kao sredstvo za pojačavanje crkvenoga besedništva, Hrišćanski vesnik, 20, 8-9 (1903), 337-344.

56 Usp. Isto. 


\subsection{Vodstvo}

Prva polovica 19. stoljeća, kad je srpskopravoslavnog stanovništva više pod austrijskim nego pod srbijanskim vladarima, u znaku je prevlasti kultura društveno razvijenijih podanika Habsburgovaca, a u drugoj polovici stoljeća postupno prevladavaju političke te druge orijentacije i institucije iz Srbije. »Više ne postoji kulturna neravnoteža «, nego su se »dvije sredine izjednačile «, a »od osamdesetih godina Kraljevina i u kulturi preuzima vodstvo«, pri čemu je »simbolično djelovanje Kraljevske srpske akademije, osnovane 1886. godine, u kojoj su okupljeni istaknuti znanstvenici i umjetnici cijelog srpskog prostora «, da bi »kulturno vodstvo Beograda« postalo »nedodirljivo nakon 1903.«(godina Majskog prevrata). ${ }^{57}$

Poslije zakašnjelih početaka modernizacije, Srbija na prijelazu 19. u 20. stoljeće još manje postiže u prosvjećivanju masa, ekonomskom i općem društvenom napretku, a više u sferama koje su bitne za državu (poglavito vojska) ili su primarno funkcionirale kao dio visoke kulture u najširem smislu. Primjerice, napredak i u filozofiji pokazuju osobito radovi Mihaila Vujića, Ljubomira Nedića, Božidara Kneževića i Branislava Petronijevića. Svjetovno govorništvo »gotovo ni po čemu nije zaostajalo« za onim u europskim zemljama s razvijenijim političkim životom, kulturom, znanošću i prosvjetom. ${ }^{58}$ Primjerice Dimitrije Tucović, »jedan od značajnijih govornika svoga doba«, i Dragiša Lapčević, koji je govorničku vještinu pokazivao i u Narodnoj skupštini, bili su čelnici rubne Srpske socijaldemokratske partije (osnovane 1903.). ${ }^{59} \mathrm{~S}$ druge strane, »veliki i čest govornik «, koji se u parlamentu stalno pozivao na "pradedovske kosti«, bio je i protojerej Milan Đurić, predsjednik zastupničkog kluba Radikalne stranke (Nikole Pašića). ${ }^{60}$

Već to što je Srbija bogosloviju, nužnu za formiranje govornika, dobila 42 godine poslije Karlovačke mitropolije pokazuje različite startne pozicije, ali poslije Pravoslavna crkva u Srbiji (autokefalna od 1879., nakon što je na Berlinskom kongresu priznata nezavisnost države) ima povoljniji društveno-politički okvir za razvoj. U Srbiji je pravoslavlje državna religija, no civilna vlast, iako Crkvu koristi za svoje ciljeve, ne miješa se u njezine poslove tako što ograničava ili sprječava naviještanje evanđelja. Ali, Beograd ne preuzima vodstvo u praksi i/ili teoriji propovjedništva.

Pokazatelj ravnoteže bili bi beogradski Pastir, prvi srbijanski crkveni list koji je održao periodičnost, te novosadska Beseda: oba glasila izlaze od 1868. do 1870. godine. Pastir je objavljivao informativne i druge tekstove, prijevode i »besede sveštenika, sveštenomonaha i bogoslovaca iz Mitropolije beogradske (Srpske Crkve u Kneževini Srbiji) i Mitropolije karlovačke«. ${ }^{61}$ Ambicioznija Beseda

57 Usp. Ćirković, Srbi, 259.

58 Usp. Đorđević, Besedništvo, 149.

59 Usp. Isto, 153-155.

60 Usp. L. Perović, Dominantna i neželjena elita: Beleške o intelektualnoj i političkoj eliti u Srbiji (XXXXI vek), Beograd, 22016, 318-319.

61 Usp. I. Marković, Počeci književnog rada učenika i profesora beogradske Bogoslovije. 
imala je prilog Duhovni zbornik, u kojem su tiskani prijevodi propovijedi Ivana Zlatoustoga i drugih crkvenih otaca te, primjerice, Fénelona, a od domaćih autora nekoliko je propovijedi objavio i Jevtimije Vukadinović. Taj je zemunski protojerej u predgovoru svoje zbirke besjeda napisao da hoće li i koliko one moći poslužiti napretku »zapuštenog nam naroda «, to će valjda pravedna kritika »presuditi «, »imajući pri tom u vidu, da smo mi Srbi u pogledu crkvene rečitosti — sa malim izuzetkom — jošte početnici «. ${ }^{6}$

Dio odgovora na pitanje o razlozima takvog stanja nalazi se u tvrdnji da je kod Srba (u Srbiji, BiH i ostalim zemljama) bilo »dobrih propovjednika«, čije su »kratke, jezgrovite propovijedi pune patriotizma« imale »izvjestan uspjeh«, te se u seoskim crkvama mogu »reprodukovati« i propovijedi od prije 50 godina - jer »naš težak nije za to vrijeme u kulturi skoro ni koraka odmakao «. ${ }^{63} \mathrm{O}$ tome koliko se u kulturi odmaknulo pokazuje golemi postotak nepismenih i u Srbiji, te navod upućuje na zaključivanje kako na smjeni stoljeća u patrijarhalnim društvima, koja reproduciraju male potrebe, teško može postojati interes za razvoj propovijedi.

No, čak da je tako - zadaća je crkvenih profesionalaca razvijati propovijedanje u svim prilikama. Svećenici su većinom nesavjesni propovjednici sigurno i zato što u crkvenom vodstvu nemaju uzore i poticatelje. Blago rečeno, »nije bilo lako razbiti debelu koru ravnodušnosti« koja je obavila $i$ »crkvene velikane« u obje mitropolije, uključujući mitropolita Mihaila, koji nisu podržavali širenje periodike, ${ }^{64}$ koja je nužan alat razvoja homiletike te uopće teologije i religijske zajednice. Istraživač tvrdi da je »brazda« koju su zaorali Pastir i Beseda bila plodnija u Beogradskoj nego u Karlovačkoj mitropoliji. ${ }^{65}$ Ali, ni na početku 20. stoljeća — kad je u Beogradskoj mitropoliji 2,500.000, a u Karlovačkoj 1,200.000 vjernika - većina homiletskih i drugih priloga u neslužbenom dijelu Glasnika Pravoslavne crkve u Kraljevini Srbiji i drugim, sve brojnijim, crkvenim glasilima još nije na razini osobito Bogoslovskog glasnika iz Srijemskih Karlovaca. Uostalom, kao što je pisalo u časopisu Svešteničkog udruženja, »u našim redovima imamo vrlo retke dobre besednike - i kako u toj strani naše službe vodimo računa, dočekaćemo da će nas u tome preteći i seoske ćate«, a da se i pisar(čić)i ne bi pokazali boljima od svećenika, požarevački ogranak te staleške udruge odlučio je organizirati propovjednički kružok. ${ }^{66}$

62 Usp. J. Vukadinović, Duhovne besede, Pančevo, 1879, [V].

63 Usp. J. Davidović, Jedan novi propovjednik, Srpski sveštenik, 2, 11 (1913), 334.

64 Usp. B. A. Cisarž, Jedan vek periodične štampe Srpske pravoslavne crkve I: Bibliografski opis časopisa i listova sa pregledom-sadržajem svih radova objavljenih u njima od 1868-1970, Beograd, 1986, 20-21.

65 Usp. Isto, 23.

66 Usp. M. Branković, Usavršavanje u besedništvu, Vesnik Srpske crkve, 18, 4 (1907), 317. 


\section{Zaključak}

Tvrdnja da su Srbi u crkvenom govorništvu još početnici, što je 1879. zapisao Jevtimije Vukadinović, najvećim je dijelom vrijedila i poslije 20-25 godina. Sudeći prema vladikama i svećenicima koji se navode kao značajni govornici te drugim pokazateljima, ocjena o početništvu više se odnosila na srpskopravoslavno govorništvo u Kraljevini Srbiji nego u Kraljevini Hrvatskoj i Slavoniji (u Translajtaniji).

Za propovjedništvo u Srbiji u 19. stoljeću najvažniji je dugogodišnji mitropolit Mihailo Jovanović, značajni govornik koji je (p)ostavio brojna pomagala za razvoj te djelatnosti po ruskim uzorima, ali oni nisu bili osobito poticajni. Ni na samom početku 20. stoljeća, nije se bitno odmaknulo od zapuštenosti propovijedanja poput one početkom 19. stoljeća, tijekom i neposredno nakon turkokracije, dakle u mnogo nepovoljnijim društvenim i kulturnim prilikama. Razlozi za to što ne samo da nema više uzornih govornika nego je i malo dobrih, odnosno što se propovijeda malo i slabo, nisu bili izvan same izrazito nacionalno orijentirane državne religijske zajednice. Na temelju uvida u stanje klera, jedine bogoslovije, homiletike i periodike može se zaključiti da u uvjetima crkvene autonomije (1831.) i autokefalnosti (1879.) u sve slobodnijoj državi nema plodne suradnje faktora (sudionika i sredstava) razvoja propovjedništva, za što je najodgovorniji episkopat.

U Beogradskoj mitropoliji propovijedanje i njegovi razvojni uvjeti teško smanjuju zaostatak za onima u Karlovačkoj mitropoliji. Nema ozbiljnih naznaka da će do pomicanja gravitacijskog središta prema matičnomu srpskomu području (odnosno Beogradu), koje je obavljeno u politici te visokoj kulturi i prosvjeti (Akademija, Univerzitet), doći i u propovjedništvu (i drugim crkvenim aktivnostima). Crkva ne uspijeva pratiti razvoj civilnog govorništva, filozofije i drugih sektora srbijanskog društveno-kulturnog života u modernizaciji - iako je taj proces, vidi se i po visokom stupnju nepismenosti, prespor i plitak. 
The Art of Preaching in 19th Century Serbia

Mirko Mlakar*

Summary

The article deals with the art of preaching in the Serbian Orthodox Church in 19th century Serbia, primarily in the socio-cultural context. Also, the effects of the work of the long-time Metropolitan, Mihailo Jovanovic, are examined. A study of the representatives of the only existing seminary as well as other (developmental) factors involved in the art of preaching sermons leads us to the conclusion that even toward the end of the 19th century, the Belgrade Metropolitanate did not achieve the level of the Karlovac Metropolitanate (in Austro-Hungary). While in the transition from the 19th to the 20th centuries in the Kingdom of Serbia we can see the results of the development of (high) secular culture in its broadest sense, including also the field of rhetoric, the art of preaching, which, being modelled after Russia, was not significantly enriched. The causes for neglecting the development of preaching skills were to be found within the overtly nationally oriented religious community which was loyal to the state.

Key words: art of preaching, Dukedom/Kingdom of Serbia, Belgrade Metropolitanate, Karlovac Metropolitanate, Mihailo Jovanović, orthodox seminaries

* Mirko Mlakar, Ph.D. Address: Hasana Kikića 7, 10140 Zagreb, Croatia. E-mail: mvmlakar@ gmail.com 